This is an author produced version of a paper published in Journal of Dairy Research. This paper has been peer-reviewed.

Citation for the published paper:

Åkerstedt, M., Björck, L., Persson Waller, K., and Sternesjö, Å (2006) Biosensor assay for determination of haptoglobin in bovine milk. Journal of Dairy Research. 73:3, 299-305. ISSN: 0022-0299. http://dx.doi.org/10.1017/S0022029906001774

Access to the published version may require journal subscription. Published with permission from: Cambridge University Press

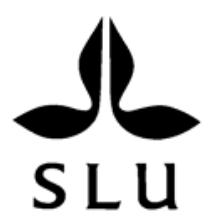

Epsilon Open Archive http://epsilon.slu.se 


\title{
Biosensor assay for determination of haptoglobin in bovine milk
}

\author{
Maria Åkerstedt ${ }^{1}$, Lennart Björck ${ }^{1}$, Karin Persson Waller ${ }^{2,3}$ and Åse Sternesjö ${ }^{1 *}$ \\ ${ }^{1}$ Department of Food Science, PO Box 7051, Swedish University of Agricultural Sciences, SE-750 07 Uppsala, Sweden \\ ${ }^{2}$ Department of Pigs, Poultry and Ruminants, National Veterinary Institute, SE-751 89 Uppsala, Sweden \\ ${ }^{3}$ Department of Clinical Sciences, PO Box 7039, Swedish University of Agricultural Sciences, SE-750 07 Uppsala, Sweden
}

Received 13 May 2005 and accepted for publication 23 November 2005

Despite more than 30 years of research into mastitis diagnostics, there are few alternatives to the somatic cell count (SCC) in practical use for identification of cows with subclinical mastitis. Mastitis is not only an animal welfare problem, but also affects the yield, composition and technological properties of milk. Hence, dairy cooperatives give farmers a premium quality payment to encourage low SCC although there is no clear scientific data defining the level of SCC in bulk tank milk that is associated with additional benefits in terms of milk quality. Recent research on alternative markers for inflammatory reactions in the lactating cow, e.g. in mastitis, includes investigations of the acute phase protein, haptoglobin $(\mathrm{Hp})$. So far, the content of $\mathrm{Hp}$ in milk has mainly been studied in relation to mastitis diagnostics, with little attention given to its importance for milk composition and technological properties. At present, $\mathrm{Hp}$ in milk is measured using ELISA, but this technique is not suitable for routine large-scale analysis. In recent years, optical biosensor technology has been used for automated and rapid quantitative analysis of different components in milk, but so far not for analysis of acute phase proteins. The aim of the present study was to develop a rapid and sensitive biosensor method to determine $\mathrm{Hp}$ in milk. An affinity sensor assay based on the interaction between $\mathrm{Hp}$ and haemoglobin was developed using surface plasmon resonance (SPR) biosensor technology. The assay was used to analyse $\mathrm{Hp}$ in composite milk samples from cows without any clinical signs of mastitis and quarter milk samples with a weak to strong reaction in the California Mastitis Test (CMT). A commercial ELISA for determination of $\mathrm{Hp}$ in milk was used for comparison. The limit of detection (LOD) of the biosensor assay was determined as $1.1 \mathrm{mg} / \mathrm{l}$. Within-assay and betweenday variations were determined both with bulk tank milk spiked with human $\mathrm{Hp}$ and with composite milk samples containing bovine $\mathrm{Hp}$. Coefficients of variation varied between 3.6 and $8.6 \%$ at concentrations between 4.0 and $12 \mathrm{mg} / \mathrm{l}$, respectively. Agreement between the results obtained by the biosensor assay and the ELISA was satisfactory; however, the results obtained by the biosensor were generally lower than the results obtained by the ELISA. Possible explanations for this observation are discussed.

Keywords: Mastitis diagnostics, dairy cow.

In spite of more than 30 years of research into mastitis diagnostics, the milk somatic cell count (SCC) is still the standard method used to identify cows and udder quarters with subclinical mastitis. Besides being an animal welfare problem, mastitis affects the yield, composition and processing properties of the milk, with a negative impact on the quality of the final dairy product (Roux et al. 2003). SCC is therefore also used to assess milk quality at the bulk tank level and according to EC Directive 853/2004, the SCC of the bulk tank milk must be $<400000$ cells $/ \mathrm{ml}$

*For correspondence; e-mail: Ase.Sternesjo@Imv.slu.se
(EC, 2004). Despite a lack of unambiguous scientific evidence showing at what level of SCC the bulk tank milk composition is negatively affected, the pressure on milk producers to lower the SCC below present standards has increased. In Sweden, dairy co-operatives generally give a bonus payment when the SCC is $<150000-200000$ cells/ $\mathrm{ml}$. With increasing herd size and number of automated milking systems there is a demand for rapid, large scale analysis of milk to allow early identification of infected quarters (Grönlund et al. 2003; Pyörälä, 2003). Various techniques have been suggested and evaluated as alternatives to SCC, including changes in serum proteins, enzymes, ions and lactose (Pyörälä, 2003). At present, 
electrical conductivity is the only method used commercially in automated milking systems despite the fact that electrical conductivity is not considered to be sensitive enough to detect subclinical mastitis (Nielen et al. 1995).

In the last decade there has been an increasing interest in the possibility of using acute phase proteins (APP) in veterinary diagnosis. APP are a group of blood proteins that change dramatically in concentration upon challenge, e.g. infection, inflammation or trauma. The proteins can be classified according to the magnitude of their increase (positive APP) or decrease (negative APP), and the response pattern of APP is species specific. One of the major APP in cattle is haptoglobin $(\mathrm{Hp})$. $\mathrm{Hp}$ is mainly produced by hepatocytes and its synthesis increases upon stimulation by different cytokines (Gruys et al. 1994; Murata et al. 2004; Petersen et al. 2004). Measured in serum, $\mathrm{Hp}$ is an unspecific marker of disease as an increased concentration can be a result of a number of causes. In mastitis, the permeability between the milk and blood compartments increases and hepatically derived $\mathrm{Hp}$ can enter the milk (Eckersall et al. 2001). Hp in milk thus becomes a specific marker of mastitis, since the $\mathrm{Hp}$ concentration in milk from healthy quarters is low or undetectable (Eckersall et al. 2001; Grönlund et al. 2003; Grönlund et al. 2005). Recent research indicates that $\mathrm{Hp}$ may also be synthesized locally in the mammary gland, as Hiss et al. (2004) demonstrated Hp mRNA expression in mammary gland tissue by real-time PCR.

$\mathrm{Hp}$ in milk is commonly determined by commercially available or in-house immunoassays. Many of these assays become cumbersome and time consuming when used for large-scale analysis. Compared with human medicine, there is a lack of APP tests for routine analysis in veterinary medicine (Eckersall, 2004). During the last decade, several applications of optical biosensor technology for quantitative analysis of different components and residues in milk have been described (Baxter et al. 2001; Gillis et al. 2002; Indyk et al. 2002; Samsonova et al. 2002; Nygren et al. 2003; Dupont et al. 2004; Gustavsson et al. 2004; Haasnoot et al. 2004). The main advantage of the biosensor over ELISA, is the automated and rapid analysis, each sample requiring approximately 5-10 min. The aim of the present study was to develop an optical biosensor assay for $\mathrm{Hp}$ based on the strong interaction between haemoglobin and $\mathrm{Hp}$. The resulting assay will in our future work be used to determine whether APP, in addition to being used as indicators of udder health, also may function as biomarkers for raw milk quality.

\section{Materials and Methods}

\section{Instrumentation}

The optical biosensor used was a Biacore $Q$ instrument (Biacore AB, SE-754 50, Uppsala, Sweden) with Biacore Q
Control Software (version 3.0.1) for instrument operation and BIA evaluation (version 3.2) for data handling.

\section{Reagents}

Sensor Chip CM5 (research grade), HBS-P buffer $\mathrm{pH} 7 \cdot 4$ (10 m 4 4-[2-hydroxyethyl] piperazine-1-ethane-sulphonic acid (Hepes), $150 \mathrm{~mm}-\mathrm{NaCl}, 0.005 \%$ (v/v) surfactant $\mathrm{P}-20)$, amine coupling kit (400 mm-N-ethyl-N'-(3-ethylaminopropyl) carbodiimide hydrochloride (EDC), $100 \mathrm{~mm}$ $\mathrm{N}$-hydroxysuccinimide (NHS) and $1 \mathrm{~m}$-ethanolamine hydrochloride) and SDS (0.5\% (w/v) sodium dodecyl sulphate) were obtained from Biacore AB (SE-75450, Uppsala, Sweden).

Owing to the unavailability of bovine $\mathrm{Hp}$ at the time this study was initiated, the human form of the protein was used (Biogenesis, Poole, UK). Bovine haemoglobin was obtained from Sigma (St Louis MO, USA). Before use, haemoglobin was stabilized in a buffer containing $\mathrm{K}_{3} \mathrm{Fe}(\mathrm{CN})_{6} \quad(200 \mathrm{mg} / \mathrm{l}), \quad \mathrm{KCN} \quad(50 \mathrm{mg} / \mathrm{l})$ and $\mathrm{KH}_{2} \mathrm{PO}_{4}$ $(140 \mathrm{mg} / \mathrm{l})$. Acetate buffer $(0.01 \mathrm{M}, \mathrm{pH} 3 \cdot 8)$ was used for immobilization of $\mathrm{Hp}$ to the sensor surface and PBS $(0 \cdot 01 \mathrm{M}, \mathrm{pH} 7 \cdot 4)$ was used for dilution of $\mathrm{Hp}$ during preparation of the Hp standards.

\section{Milk samples}

Bulk tank milk and cow composite milk samples $(n=43)$ from clinically healthy cows, i.e. cows with no observable signs of any disease, were collected from the University dairy herd. Quarter milk samples $(n=28)$ with weak to strong reactions in the California Mastitis Test (CMT) were provided by the National Veterinary Institute (Uppsala, Sweden). Most of the latter samples (25 out of 28) were bacteriologically positive. Since the biosensor method is based on the interaction between added haemoglobin and $\mathrm{Hp}$, haemoglobin from blood will disturb the analysis. Consequently, no milk samples that by visual assessment were concluded to contain blood were included in the study. Milk samples were defatted by centrifugation for $5 \mathrm{~min}$ at $750 \mathrm{~g}$ and stored at $-70{ }^{\circ} \mathrm{C}$ until analysed.

\section{Haptoglobin ELISA}

A commercial Hp-ELISA (Phase ${ }^{\mathrm{TM}}$ Bovine Haptoglobin Enzyme Immunoassay, Tridelta Development Ltd, Bray, Co. Wicklow, Ireland) was used for comparison with the biosensor assay. In the ELISA, the wells are coated with haemoglobin that will bind free $\mathrm{Hp}$ in the sample. A Horse Radish Peroxidase (HRP)-labelled anti-Hp monoclonal antibody is added, which will bind to the captured $\mathrm{Hp}$. Finally, a tetramethyl benzidine (TMB) substrate solution is added, and the colour intensity obtained is proportional to the concentration of $\mathrm{Hp}$ in the sample. The test was performed according to the manufacturer's instructions and the claimed limit of detection (LOD) of the ELISA was $0.3 \mathrm{mg} / \mathrm{l}$. 


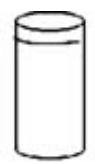

Negative sampleHp absent

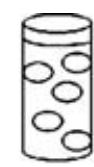

Positive sampleHp present
Mixing of sample and haemoglobin

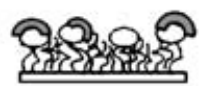

Negative sampleincreased mass on the surface: high response

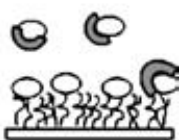

Positive sample-no/less increased mass on the surface: low response

\section{Haptoglobin \& Haemoglobin

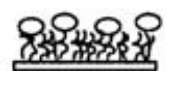 \\ Haptoglobin ( $\mathrm{Hp})$ bound to the sensor surface}

Fig. 1. Schematic illustration of the competitive biosensor assay principle. The milk sample is mixed with haemoglobin before injection over a sensor surface with haptoglobin $(\mathrm{Hp})$ immobilized. With no Hp present in the sample, the haemoglobin will bind to immobilized $\mathrm{Hp}$ on the sensor surface. When $\mathrm{Hp}$ is present in the sample, it will form a complex with added haemoglobin and inhibit haemoglogin-binding to the surface. The amount of haemoglobin binding to the surface is therefore inversely proportional to the amount of $\mathrm{Hp}$ in the sample.

\section{Haptoglobin biosensor assay}

Principle of assay. This competitive assay is based on the strong interaction between $\mathrm{Hp}$ and haemoglobin, and the principle is explained in Fig. 1. The milk sample is mixed with bovine haemoglobin before injection over a sensor surface with immobilized Hp. When no $\mathrm{Hp}$ is present in the sample haemoglobin will bind to immobilized Hp on the sensor surface. Since the detection principle is based on mass-dependent changes in refractive index at the sensor surface, haemoglobin binding to the surface results in an increased response. When $\mathrm{Hp}$ is present in the sample, it will form a complex with added haemoglobin and inhibit haemoglobin binding to the surface. The amount of haemoglobin binding to the surface is therefore inversely proportional to the amount of $\mathrm{Hp}$ in the sample.

Preparation of biosensor surface. Haptoglobin (500 mg/l) in $0.01 \mathrm{M}$-acetate buffer $\mathrm{pH} 3.8$ was immobilized to a CM5 sensor chip using the standard amine coupling procedure with a constant flow rate of $5 \mu \mathrm{l} / \mathrm{min}$ during the entire immobilization procedure. Briefly, the carboxymethylated dextran surface was activated by injection of a mixture containing equal amounts of EDC (400 mм) and NHS (100 mm) for $7 \mathrm{~min}$. The ligand, i.e. Hp, was injected for $7 \mathrm{~min}$ and the NHS-esters formed during activation reacted with primary amino groups of the ligand. After coupling, remaining active NHS-esters were deactivated with $7 \mathrm{~min}$ injection of $1 \mathrm{M}$-ethanolamine.

Preparation of standards. Hp was dissolved in $0 \cdot 01$ M-PBS $\mathrm{pH} 7 \cdot 4$ and added to bulk tank milk in different concentrations. The stock solution $(1000 \mathrm{mg} / \mathrm{l})$ was used to prepare milk samples with final $\mathrm{Hp}$ concentrations of $1 \cdot 25,2 \cdot 5,5,10,20$ and $40 \mathrm{mg} / \mathrm{l}$ for construction of a standard curve.

Analysis of composite and quarter milk samples. Frozen milk samples were thawed at room temperature before analysis. Milk samples were pipetted into a microtitre plate and automatically mixed with haemoglobin diluted in HBS-P buffer $(2.5 \mathrm{mg} / \mathrm{l})$. The mixture $(10 \%$ sample and $90 \%$ haemoglobin solution) was then injected $(30 \mu \mathrm{l})$ over the sensor surface. After each measurement the surface was regenerated by injection of $30 \mu \mathrm{l}$ of $2 \cdot 1 \mathrm{~mm}-$ SDS. HBS-P was used as running buffer at a flow rate of $30 \mu \mathrm{l} / \mathrm{min}$ throughout the analysis.

To see whether variations in the sample matrix would affect the results, all milk samples were initially diluted with bulk tank milk negative in the Hp-ELISA before analysis $(1: 2,1: 5,1: 10,1: 20$ etc. depending on $\mathrm{Hp}$ concentration in the sample). For samples with slightly elevated concentrations $(1-5 \mathrm{mg} / \mathrm{l})$ it was found that this procedure was not necessary, since there was no observable matrix effect, and the result after the first dilution step was the same as the result for the undiluted sample. For samples with very high $\mathrm{Hp}$ levels, usually samples from cows with clinical mastitis, this procedure was necessary both to fall within the linear part of the standard curve and to overcome effects from the matrix.

Evaluation of assay performance. Hp standards were analysed according to the assay procedure and the results were used to construct calibration curves. Assay LOD was determined by analysing 20 replicates of a bulk tank milk sample negative in the Hp ELISA $(<0.3 \mathrm{mg} / \mathrm{l})$. LOD was defined as the lowest concentration corresponding to a relative response significantly different $(3 \times \mathrm{SD})$ from the average response of $20 \mathrm{Hp}$-negative samples. The precision of the assay was determined by analysis of bulk tank milk spiked with human $\mathrm{Hp}$ at two different concentrations ( 4.0 and $12 \mathrm{mg} / \mathrm{l})$ and two composite milk samples containing bovine $\mathrm{Hp}(4 \cdot 1$ and $7 \cdot 2 \mathrm{mg} / \mathrm{l}$ according to ELISA). Ten replicates of each milk sample were analysed once daily for three consecutive days. The SD 
Table 1. Precision of the haptoglobin (Hp) biosensor assay determined within assay and between days by analysis of bulk tank milk spiked with human $\mathrm{Hp}$ at two different levels (4 and $12 \mathrm{mg} / \mathrm{l}$ ) and two cow composite milk samples containing $4 \cdot 1$ and $7 \cdot 2 \mathrm{mg} / \mathrm{l}$ of bovine Hp according to ELISA

\begin{tabular}{|c|c|c|c|}
\hline \multicolumn{2}{|c|}{ Bulk tank milk spiked with human $\mathrm{Hp}$} & \multicolumn{2}{|c|}{ Cow composite milk sample } \\
\hline $4.0 \mathrm{mg} / \mathrm{l}$ & $12 \cdot 0 \mathrm{mg} / \mathrm{l}$ & $4 \cdot 1 \mathrm{mg} / \mathrm{l}$ & $7 \cdot 2 \mathrm{mg} / \mathrm{l}$ \\
\hline $4 \cdot 8$ & $12 \cdot 6$ & $4 \cdot 1$ & $6 \cdot 4$ \\
\hline $0 \cdot 17(3 \cdot 6)$ & $0 \cdot 70(5 \cdot 5)$ & $0 \cdot 18(4 \cdot 3)$ & $0 \cdot 44(6 \cdot 8)$ \\
\hline $4 \cdot 5$ & $11 \cdot 8$ & $4 \cdot 1$ & $6 \cdot 5$ \\
\hline $0 \cdot 26(5 \cdot 9)$ & $1 \cdot 01(8 \cdot 6)$ & $0 \cdot 24(5 \cdot 9)$ & $0 \cdot 29(4 \cdot 5)$ \\
\hline
\end{tabular}

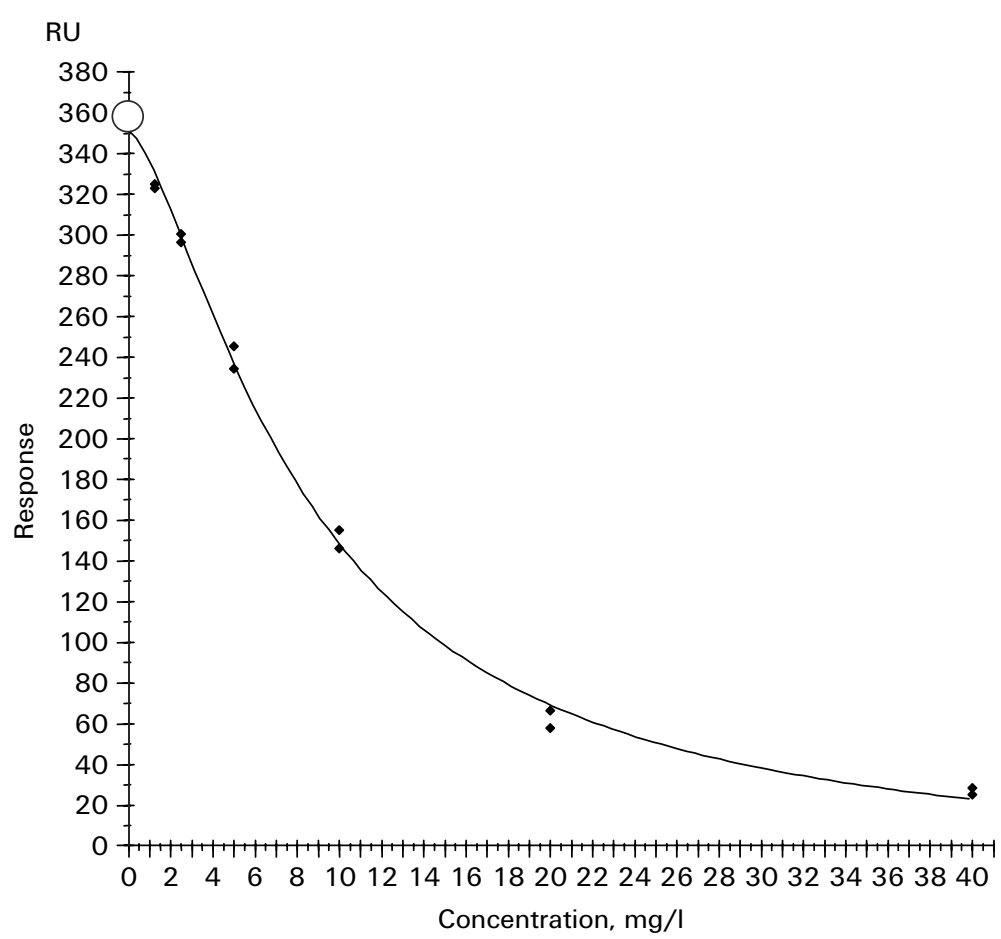

Fig. 2. Haptoglobin $(\mathrm{Hp})$ calibration curve obtained by duplicate analysis of bulk tank milk spiked with human $\mathrm{Hp}$ using the biosensor assay.

for the analysed concentrations was determined within and between days.

The agreement between results obtained with the biosensor assay and the ELISA was evaluated using Wilcoxon single rank test (Minitab Inc., version 14, 2003, State College, PA, USA).

\section{Results}

A typical calibration curve for the $\mathrm{Hp}$ biosensor assay is presented in Fig. 2. The average response in the analysis of Hp-negative samples $(n=20)$ was $403 \pm 3 \mathrm{RU}$, resulting in a background level of $0 \cdot 2 \pm 0 \cdot 3 \mathrm{mg} / \mathrm{l} \mathrm{Hp}$ and a detection limit of $1.1 \mathrm{mg} / \mathrm{l}$. The CV of the assay varied between $3.6 \%$ and
$6 \cdot 8 \%$ within assay, and between $4.5 \%$ and $8 \cdot 6 \%$ between days (Table 1) for bulk tank milk spiked with human $\mathrm{Hp}$ (4 and $12 \mathrm{mg} / \mathrm{l}$ ) and cow composite milk samples with bovine $\mathrm{Hp}(4 \cdot 1$ and $7 \cdot 2 \mathrm{mg} / \mathrm{l})$.

Of the analysed composite milk samples from cows with no observable signs of mastitis, 36 out of 43 samples were Hp-negative in both ELISA and biosensor method. In the remaining 7 samples, the ELISA detected concentrations varying between 1 and $12 \mathrm{mg} / \mathrm{l}$, whereas the biosensor assay only detected $\mathrm{Hp}$ in the 3 samples with the highest concentrations as measured by the ELISA (Table 2).

When analysing quarter milk samples with weak to strong CMT reactions, 24 out of 28 samples had Hp concentrations $<50 \mathrm{mg} / \mathrm{l}$ whereas the remaining 4 samples contained higher $\mathrm{Hp}$ concentrations (Table 3). Results 
Table 2. Haptoglobin $(\mathrm{Hp})$ determined with the biosensor assay and the ELISA in composite milk samples from cows with no clinical signs of mastitis

\begin{tabular}{lll} 
& \multicolumn{2}{c}{ Haptoglobin $(\mathrm{mg} / \mathrm{l})$} \\
\cline { 2 - 3 } No. of samples & ELISA & Biosensor \\
36 & $<$ LOD & $<$ LOD \\
1 & 12 & 7 \\
1 & 7 & 4 \\
1 & 3 & 2 \\
1 & 2 & $<$ LOD \\
3 & 1 & $<$ LOD
\end{tabular}

Table 3. Haptoglobin $(\mathrm{Hp})$ determined with the biosensor assay and ELISA in quarter milk samples from cows with weak to strong reactions (1-3) in the California Mastitis Test (CMT)

\begin{tabular}{|c|c|c|c|}
\hline \multirow{2}{*}{$\begin{array}{l}\text { Milk } \\
\text { sample ID }\end{array}$} & \multicolumn{2}{|c|}{ Haptoglobin (mg/l) } & \multirow{2}{*}{$\begin{array}{l}\text { CMT } \\
\text { score }\end{array}$} \\
\hline & ELISA & Biosensor & \\
\hline 2060.4 & 154 & 143 & 2 \\
\hline 2045.2 & 120 & 77 & 3 \\
\hline 2060.3 & 106 & 93 & 3 \\
\hline 2045.3 & 86 & 51 & 2 \\
\hline 2067.2 & 46 & 24 & 2 \\
\hline 2024.2 & 43 & 20 & 3 \\
\hline 2048.2 & 40 & 27 & 1 \\
\hline 2058.3 & 38 & 26 & 3 \\
\hline 2038.3 & 36 & 25 & 3 \\
\hline 2020.3 & 25 & 23 & 3 \\
\hline 2043.1 & 20 & 14 & 2 \\
\hline 2023.3 & 15 & 9 & 2 \\
\hline 2039.2 & 12 & 4 & 2 \\
\hline 2016.3 & 10 & 5 & 2 \\
\hline 2036.2 & 10 & 18 & 3 \\
\hline 2045.4 & 10 & 8 & 1 \\
\hline 2039.4 & 9 & 6 & 3 \\
\hline 1602.2 & 8 & 8 & 2 \\
\hline 2016.4 & 7 & 8 & 2 \\
\hline 2070.3 & 4 & 3 & 2 \\
\hline 2037.3 & 3 & 2 & 2 \\
\hline 2044.1 & 3 & 2 & 3 \\
\hline 2068.2 & 3 & 1 & 2 \\
\hline 1603.2 & 2 & 2 & 2 \\
\hline 2022.3 & 2 & 1 & 3 \\
\hline 1564.4 & 1 & 2 & 1 \\
\hline 1619.2 & $0 \cdot 5$ & 0 & 3 \\
\hline 1600.3 & $0 \cdot 5$ & 0 & 3 \\
\hline
\end{tabular}

obtained by the biosensor assay were generally lower than by ELISA, and the difference between the two methods seemed to increase with increasing $\mathrm{Hp}$ concentrations (Fig. 3).

\section{Discussion}

To our knowledge, this is the first application of optical biosensor technology for determination of APP. The first

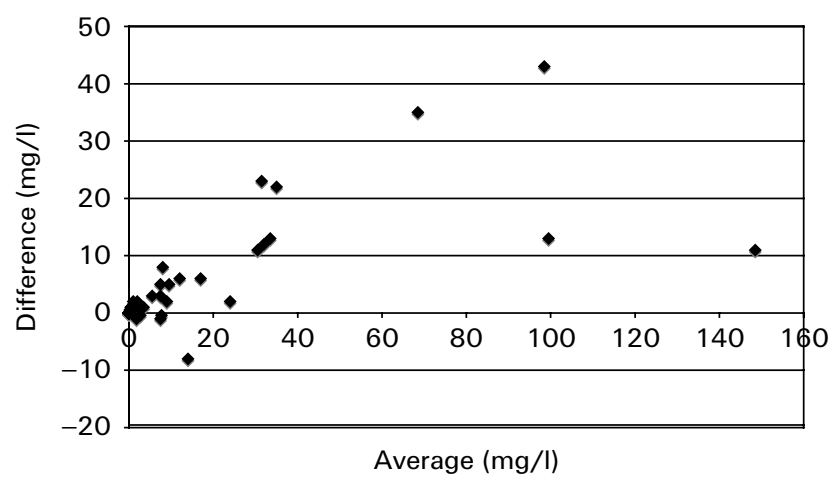

Fig. 3. Bland-Altman plot illustrating the agreement between the ELISA and biosensor assays in the determination of haptoglobin $(\mathrm{Hp})$ in milk. Average $\mathrm{Hp}$ concentration and the difference between ELISA and biosensor assay on $x$-axis and $y$-axis, respectively.

commercially available test kit for $\mathrm{Hp}$ analysis (Phase ${ }^{\mathrm{TM}}$ Range Haptoglobin Assay, Tridelta Development Ltd, Bray, Co. Wicklow, Ireland) was introduced in the late 1990s. This method is based on the conserved peroxidase activity of the Hp-haemoglobin complex at low $\mathrm{pH}$. However, this principle makes the method unsuitable for analysis of $\mathrm{Hp}$ in milk owing to interference by endogenous lactoperoxidase activity. Recently published investigations of $\mathrm{Hp}$ in milk have instead used ELISA based on monoclonal antibodies against bovine $\mathrm{Hp}$ (Grönlund et al. 2003; Hiss et al. 2004). The biosensor assay described in this paper is, like the early methods for determination of $\mathrm{Hp}$ in serum, based on the strong interaction between $\mathrm{Hp}$ and haemoglobin (Makimura \& Suzuki, 1982). With the biosensor assay this principle is applicable also to milk, since detection is not based on peroxidase activity but changes in mass on the sensor surface. During development of the biosensor assay both a direct assay with haemoglobin on the surface, and a competitive assay, adding known amounts of haemoglobin to the sample before injection across a $\mathrm{Hp}$ surface, were investigated. For unknown reasons, we did not succeed in developing a direct assay. One possible explanation could be that immobilized haemoglobin is poorly exposed on the surface and as a consequence, $\mathrm{Hp}$, which is a much larger molecule, cannot interact with the binding site. This approach would need further work, for example a linker to attach $\mathrm{Hp}$ to the surface. In contrast, the development of the competitive assay was quite straightforward and this format was chosen for further studies.

Regeneration of the biosensor surface, i.e. dissociation of the interaction between ligand and the interacting compound, is normally achieved by injection of a buffer with low or high $\mathrm{pH}$. This procedure was not sufficient to dissociate the strong interaction between $\mathrm{Hp}$ and haemoglobin and various regeneration solutions were evaluated with little success. Increasing the ionic strength, adding chaotropic agents ( $\mathrm{NaSCN}$, guanidine- $\mathrm{HCl}$ ) and/or 
ethylene glycol had no effect or reduced the activity of the surface. Finally, it was found that a weak solution $(2 \cdot 1 \mathrm{~mm})$ of SDS did dissociate the complex efficiently without damaging the immobilized $\mathrm{Hp}$, and this procedure was subsequently used for successful regeneration of the sensor surface.

The ability of the biosensor assay to detect $\mathrm{Hp}$ in milk agreed satisfactorily with the ELISA. The precision of the method was high both within assay and between days, but the biosensor assay had a higher LOD $(1 \cdot 1 \mathrm{mg} / \mathrm{l})$ than the ELISA $(0.3 \mathrm{mg} / \mathrm{l}$ as claimed by the manufacturer). Furthermore, the concentrations obtained by the biosensor were generally lower than the concentrations obtained by ELISA. A Bland-Altman plot of the differences between the two assays (ELISA - biosensor) against the average concentration suggests that the difference between the two tests, as well as the variation, increases with increasing $\mathrm{Hp}$ concentration (Fig. 3). Moreover the Wilcoxon single rank test (Minitab Inc., version 14, 2003) points out that the two methods disagree significantly $(P<0 \cdot 001)$. One possible explanation might be differences in affinity between bovine haemoglobin and the human form of $\mathrm{Hp}$ used in standards and the bovine form of Hp present in milk. The human $\mathrm{Hp}$ consisted of a mixture of the three human phenotypes, Hp 1-1, Hp 2-1 and Hp 2-2. Bovine $\mathrm{Hp}$, which is highly polymerized with a molecular mass exceeding $1000 \mathrm{kDa}$ (Eckersall \& Conner, 1990; Morimatsu et al. 1991), is considered to be most similar to human Hp 2-2 (Eckersall \& Conner, 1990). In on-going studies we have therefore used the human Hp 2-2 both as ligand and in standards to see whether the differences between ELISA and biosensor assay will decrease. Moreover, after this manuscript was submitted, bovine $\mathrm{Hp}$ also has become commercially available. Our preliminary results with different $\mathrm{Hp}$ forms, however, do not suggest that the difference between ELISA and biosensor assay would depend on which $\mathrm{Hp}$ form is used as calibrator.

Another, perhaps more likely reason for the difference between the two methods, is that even the smallest blood impurities in the milk may interfere with the biosensor assay by reducing the inhibitory effect of free $\mathrm{Hp}$ on the fixed amount of added haemoglobin. Therefore samples containing blood cannot be analysed with this method and for this reason such samples always have to be eliminated. Although the samples in this study were visually examined for the presence of blood, it cannot be excluded that even the slightest elevation of haemoglobin will affect the assay. The fact that the difference in results between two methods increases at high levels (Fig. 3) could indicate that samples associated with clinical cases of mastitis are more likely to be contaminated with haemoglobin. Consequently, underestimation is more likely to occur with samples containing high $\mathrm{Hp}$ levels than with samples containing low concentrations. It is clear that the developed assay is not optimal for quantitative determination of $\mathrm{Hp}$, but it can definitely be used as a tool for semi-quantitative determinations, especially with milk from cows with no observable signs of mastitis.

Application of this type of assay is dependent on the outcome of studies on what these proteins, say in relation to milk composition. This is our first manuscript resulting from such studies and it is, therefore, too early to say anything about the usefulness of the assay. If our future studies were to show a strong correlation between elevated levels of $\mathrm{Hp}$ and changes in milk composition, then the assay could be used for raw milk quality assessment in the laboratory or on farm. In the last decade, research related to APP in food-producing animals has focused on the diagnostic value of the proteins. We consider our work, focusing on food quality and food safety, to be complementary to these studies.

In conclusion, we describe a simple and rapid method to determine $\mathrm{Hp}$ in bovine milk. It is the first biosensor assay to measure $\mathrm{Hp}$ and it is based on the strong interaction between $\mathrm{Hp}$ and haemoglobin. The biosensor assay has potential to be useful in screening of $\mathrm{Hp}$ in milk samples if future studies show that elevated levels of $\mathrm{Hp}$ correlate with altered milk composition and impaired milk quality.

We thank the Swedish Farmers' Foundation for Agricultural Research for financial support. We also thank Lotta Wall at the Department of Food Science for technical assistance, Gudrun Franzen and Lena Hagenvall at Jälla experimental farm, and Susanne André Tuvesson and co-workers at the mastitis laboratory at National Veterinary Institute, for providing milk samples.

\section{References}

Baxter GA, Ferguson JP, O'Connor MC \& Elliott CT 2001 Detection of streptomycin residues in whole milk using an optical immunobiosensor. Journal of Agricultural and Food Chemistry 49 3204-3207

Dupont D, Rolet-Repecaud O \& Muller-Renaud S 2004 Determination of the heat treatment undergone by milk by following the denaturation of alpha-lactalbumin with a biosensor. Journal of Agricultural and Food Chemistry 52 677-681

EC 2004 Regulation No 853/2004 of the European Parliament and of the Council of 29 April 2004 laying down specific hygiene rules for food of animal origin. Official Journal of the European Union L226 22-82

Eckersall PD 2004 The time is right for acute phase protein assays. Veterinary Journal 168 3-5

Eckersall PD \& Conner JG 1990 Plasma haptoglobin in cattle (Bos taurus) exists as polymers in association with albumin. Comparative Biochemistry and Physiology B-Biochemistry \& Molecular Biology 96 309-314

Eckersall PD, Young FJ, McComb C, Hogarth CJ, Safi S, Weber A, McDonald T, Nolan AM \& Fitzpatrick JL 2001 Acute phase proteins in serum and milk from dairy cows with clinical mastitis. Veterinary Record 148 35-41

Gillis EH, Gosling JP, Sreenan JM \& Kane M 2002 Development and validation of a biosensor-based immunoassay for progesterone in bovine milk. Journal of Immunological Methods 267 131-138

Grönlund U, Hulten C, Eckersall PD, Hogarth C \& Persson Waller K 2003 Haptoglobin and serum amyloid A in milk and serum during acute and chronic experimentally induced Staphylococcus aureus mastitis. Journal of Dairy Research 70 379-386 
Grönlund U, Sandgren CH \& Persson Waller K 2005 Haptoglobin and serum amyloid A in milk from dairy cows with chronic sub-clinical mastitis. Veterinary Research 36 191-198

Gruys E, Obwolo MJ \& Toussaint MJM 1994 Diagnostic significance of the major acute phase proteins in veterinary clinical chemistry: a review. Veterinary Bulletin 64 1009-1018

Gustavsson E, Degelaen J, Bjurling P \& Sternesjö Å 2004 Determination of beta-lactams in milk using a surface plasmon resonancebased biosensor. Journal of Agricultural and Food Chemistry 52 2791-2796

Haasnoot W, Smits NGE, Kemmers-Voncken AEM \& Bremer M 2004 Fast biosensor immunoassays for the detection of cows' milk in the milk of ewes and goats. Journal of Dairy Research 71 322-329

Hiss S, Mielenz M, Bruckmaier RM \& Sauerwein H 2004 Haptoglobin concentrations in blood and milk after endotoxin challenge and quantification of mammary $\mathrm{Hp}$ mRNA expression. Journal of Dairy Science 87 3778-3784

Indyk HE, Persson BS, Caselunghe MCB, Moberg A, Filonzi EL \& Woollard DC 2002 Determination of vitamin $B_{12}$ in milk products and selected foods by optical biosensor protein-binding assay: method comparison. Journal of AOAC International 85 72-81

Makimura S \& Suzuki N 1982 Quantitative determination of bovine serum haptoglobin and its elevation in some inflammatory diseases. Japanese Journal of Veterinary Sciences 44 15-21
Morimatsu M, Syuto B, Shimada N, Fujinaga T, Yamamoto S, Saito M \& Naiki M 1991 Isolation and characterization of bovine haptoglobin from acute phase sera. Journal of Biological Chemistry 266 11833-11837

Murata H, Shimada N \& Yoshioka M 2004 Current research on acute phase proteins in veterinary diagnosis: an overview. Veterinary Journal 168 28-40

Nielen M, Schukken YH, Brand A, Deluyker HA \& Maatje K 1995 Detection of subclinical mastitis from online milking parlor data. Journal of Dairy Science 78 1039-1049

Nygren L, Sternesjö Å \& Björck L 2003 Determination of folate-binding proteins from milk by optical biosensor analysis. International Dairy Journal 13 283-290

Petersen HH, Nielsen JP \& Heegaard PMH 2004 Application of acute phase protein measurements in veterinary clinical chemistry. Veterinary Research 35 163-187

Pyörälä S 2003 Indicators of inflammation in the diagnosis of mastitis. Veterinary Research 34 565-578

Roux YL, Laurent F \& Moussaoui F 2003 Polymorphonuclear proteolytic activity and milk composition change. Veterinary Research $\mathbf{3 4}$ 629-645

Samsonova JV, Baxter GA, Crooks SRH \& Elliott CT 2002 Biosensor immunoassay of ivermectin in bovine milk. Journal of AOAC International 85 879-882 